\title{
The decrease of simultaneous local election voter turnout in the Lamongan District
}

\section{Menurunnya voter turnout Pilkada serentak di Kabupaten Lamongan}

\author{
Ali Sahab \\ Department of Politicial Science, Faculty of Social and Political Sciences, Universitas Airlangga \\ Address: Jalan Dharmawangsa Dalam, Surabaya, East Java 60286 \\ E-mail: ali.sahab@fisip.unair.ac.id
}

\begin{abstract}
Voter turnout in local elections (pilkada) is a participation indicator. The local election in 2015 was different from the local elections pre-2015, as the local election in 2015 was held simultaneously. Regional electoral commissions (KPUD) gave candidates campaign facilities like posters, banners, and debates with the other candidates on local television. This socialisation was expected to increase voter turnout. The purpose of this research to ascertain the level of voter turnout in the local election held in 2015 in Lamongan, and whether it is increasing or declining. KPUD has a new role not only to do with socialisation, but KPUD must also print campaign props in line with the fairness principles. The research methods used in this study were a survey and multistage random sampling for the sampling technique. The voter turnout in the 2015 local election was just $60.47 \%$ lower than the voter turnout of the 2014 legislative election (Pileg) that reached $71 \%$. In the local election, the emotional bond between the voters and candidates is more powerful than that in a legislative election, but in the Lamongan local election 2015, it was not positively correlated. There are two main factors that influence the decrease of voter turnout. First, is the material orientation of the voters (sangu). If they do not get "Sangu", they will not vote and they prefer to work in the fields. Voters thought that leaving their job for the election should get them substitution money. Second, was the indication of cartel politics, embracing all political parties in Lamongan Regency, for them to support the same candidate who was still on duty, namely Fadeli, and two other candidates. The level of voter turnout is influenced by the material orientation of the voters and cartel politics.
\end{abstract}

Keywords: incumbent; Lamongan district; local election (Pilkada) 2015; political cartel; voter turnout

\begin{abstract}
Abstrak
Tingkat kehadiran pemilih di tempat pemilihan (voter turnout) di Pemilihan Kepala Daerah (Pilkada) merupakan salah satu indikator tingkat partisipasi pemilih. Pilkada serentak tahun 2015 berbeda dengan Pilkada sebelumnya, KPUD memfasilitasi kampanye masing-masing calon termasuk mencetak alat peraga kampanye calon. Sosialisasi yang dilakukan KPUD diharapkan juga meningkatkan voter turnout. Tujuan penelitian ini untuk mengetahui tingkat kehadiran pemilih (voter turnout) di Pilkada Kabupaten Lamongan Tahun 2015 apakah semakin meningkat atau menurun. Dengan peran baru KPUD sesuai Pasal 12, PKPU No.5 Tahun 2015 KPUD melakukan sosialisasi kepada pemilih termasuk menyetak alat peraga kampanye dengan asas keadilan. Metode penelitian dengan menggunakan survei dan teknik penarikan sampel multistage random sampling. Namun di Pilkada Kabupaten Lamongan tingkat kehadiran pemilih di Pilkada sejak tahun 2010 cenderung menurun. Pilkada 2015 voter turnout hanya 60,47\%, sedangkan pada Pemilu Legislatif (Pileg) 2014 voter turnout mencapai 71\%. Dalam Pilkada ikatan pemilih dengan calon lebih besar daripada ketika Pemilu Legislatif, namun pada Pilkada 2015 di Kabupaten Lamongan tidak berkorelasi positif. Ada dua faktor utama yang mempengaruhi menurunnya voter turnout di Pilkada 2015 Kabupaten Lamongan, yaitu orientasi material pemilih dan adanya politik kartel incumbent. Tidak adanya "sangu" atau imbalan material yang diterima pemilih membuat sebagian pemilih lebih baik tidak memilih dan tetap bekerja di sawah. Pemilih beranggapan ketika hadir untuk memilih meninggalkan pekerjaannya, sehingga perlu uang sebagai pengganti. Indikasi politik kartel oleh incumbent dengan "merangkul" semua partai politik yang ada di DPRD Kabupaten Lamongan untuk mengusung calon sama, yaitu Bupati Fadeli, dan dua calon lainnya di Pilkada 2015 Kabupaten Lamongan dari calon perseorangan. Sehingga tingkat voter turnout selain dipengaruhi oleh orientasi material pemilih juga dipengaruhi politik kartel yang cenderung dilakukan oleh incumbent.
\end{abstract}

Kata kunci: voter turnout; Pilkada Serentak 2015; Kabupaten Lamongan; incumbent; politik kartel 


\section{Introduction}

The local election (Pilkada) in Indonesia is entering a new phase with the existence of Law No. 8 Year 2015 on the Amendment to Law No. 1 Year 2015, on the Stipulation of Government Regulations in Lieu of Law No. 1 Year 2014 on the Governors, Regents and Mayors Election, into the Law of the Regional Head election. This is held every five years simultaneously throughout the territory of the Unitary State of the Republic of Indonesia (Law No. 8 Year 2015 Article 3 paragraph 1). The Local Head election is conducted simultaneously in three stages: December 2015, February 2017 and June 2018. The simultaneous local elections of Governor, Regent and Mayor are designed for budget effectiveness and efficiency, but the implementation of simultaneous local elections has also drawn criticism. Firstly, it is harming the regent that had not resigned in relation to his tenure. The submissions of the former local Heads are who still on duty and whose term will end in December 2016 has to be in accordance with the following simultaneous election and so, he will end his duty on December 2015. Secondly, it is profitable for the incumbent. The incumbent challenger candidate assesses that the campaign time is too short to be massively socialised. Third, is the lack of socialisation of the candidates by the Election Commission. The lack of socialisation by the KPUD can affect voter turnout.

The presence of voters in every election in some countries is a matter of conversation, both in established and newly consolidated democracies. The tendency of a low or decreased turnout of voters in established democracies began in the 1980s. This could be due to disappointment in the ruling regime, ignorance of the political agenda (election) or an individual being apolitical, as well as satisfaction with the government's current performance. Other factors that could lead to a decrease in voter attendance are the economic, demographic, cultural, technological and institutional factors. In the 2012 Presidential Election, the United States voter turnout rate was only 55 percent. As a pioneer of democracy, the United States, on the contrary, has quite a low level of voter attendance. Voter turnout in the United States rarely reaches $80 \%$. Only three times has the turnout reached $80 \%$, such as in 1840 , the turnout was $80.2 \%$, in 1860 , the turnout was $81.2 \%$ and in 1876 , the turnout was $81.8 \%$. The number of the voting age population and the turnout decreased by almost $50 \%$ during the election. The low turnout of voters in the United States, according to Powell (1986), is more due to the institutional arrangement of the United States, especially the party system and registration law which severely hampers voter participation. Gray \& Caul (2000) state that what influenced the decline in the turnout of voters was, amongst other things, the institutional. The proportional electoral system tends to increase turnout. Second, the party system will affect the turnout level. Jackman (1987) and Dittrich \& Johansen (1983) argue that the multi-party system supports more parties entering the political system, which in turn will increase the participation of voters. However, if the election is won by one dominant party, then it will reduce participation in the election, especially for the voting party that gets a small vote. Third, are the Economic Factors; inflation or the number of unemployed will increase voter presence in the election to correct or express dissatisfaction towards the government. Lewis-Beck \& Lockerbie (1989) assessed that the collective evaluation of voters on the economic performance of governments has a major impact on voting behaviour. The same thing was expressed by Radcliff $(1992,1996)$, in that economic growth before the election could force voters to go to the polls in greater numbers. Fourth, is group mobilisation. According to Rosenstone \& Hansen (1993) and Burnham (1965), the power of political parties, unions, and other organisations could encourage peripheral voters to go to the polling station. Organisations are often able and responsible for contacting, educating and reminding their members of their right to vote on Election Day.

There is a very high turnout of voters in authoritarian countries such as Laos's voter turnout in the 2011 elections. It reached 99.69 percent, but if viewed from the rank of democracy index, Laos is in the category of authoritarian regime ranked 156 . Other countries with a high voter turnout are Turkmenistan $93.87 \%$, Equatorial Guinea $96.45 \%$, Vietnam $99.51 \%$, Rwanda $98.50 \%$, Cuba 96.89\% and Ethiopia 93.44\%. On the contrary, according to the IDEA's (International Institute for Democracy and Electoral Assistance) data, for democratic categorised countries, the voter turnout 
tends to be low. Switzerland, as the 7th rank democratic country, has only a $49.10 \%$ voter turnout. In the 2014 Presidential Election, Indonesia had $69.58 \%$ total voter turnout, whilst for the legislative elections in 2014 , this reached $75.11 \%$.

By looking at the above phenomenon, it can be seen that when the country is able to spread the democracy message towards increasing the welfare of society and ensuring the basic life of the community as indicators, its turnout of voters tends to fall. The voters' confidence in their representatives is so high that there is low attendance at the elections, but the presence of voters in the General Election is also seen from other variables that can influence and that depend on the characteristics of the community in their use of political rights.

The decline in the turnout of voters can also be seen in the 2015 elections in Lamongan District. The downward trend in the turnout of voters can be seen in Legislative Election 2014 and Local Legislative 2005, all the way up to Local Legislative 2015. The Lamongan District elections tend to decrease in their turnout. In the Local Election 2005, the attendance rate was $72 \%$, Local Election 2010 's attendance rate was $63 / 90 \%$ and Local Elections 2015's attendance rate was $60.47 \%$, whilst Legislative Election 2014's voter attendance rate was 71\%. This shows there are factors that affect the attendance rate of the voters in each election. This does indicate the satisfaction of the democracy in Lamongan, and even indicates dissatisfaction with the leadership of the Fadeli Regent.

The Permanent Voters List (DPT) in the 2015 electoral election reached 1,081,581 voters, consisting of 533,711 male voters and 547,810 female voters. On the other hand, the competing candidates were also widely known by the public. The Fadeli Regent, as an incumbent candidate, certainly had high popularity, but that was not enough to increase voter attendance in the voting booth.

\section{Research Method}

This article is the result of research using the survey method to study and see the downward trend of the turnout of voters in Lamongan District Elections (Pilkada). From Local Election 2010 up to 2015, the turnout of voters has tended to decline. The 2015 electoral elections in Lamongan District had the lowest attendance rate. This survey was conducted to find out the factors causing the decrease of public attendance in the 2015 elections. This survey also described the turnout map in each subdistrict, in Lamongan District itself. This survey was conducted on people who have the right to vote in order to look for general trends about the factors affecting the decrease in voter turnout. The total sample was made up of 384 respondents with a multistage random sampling method.

The data collection was compiled from direct interviews with each respondent using a questionnaire. Aside from that, the researchers also conducted a direct observation of conditions in the field related to the issues and programs that became the desire of the community. The questions in the questionnaire contain the characteristics of the respondents, including residential district, sex, religion, education, employment, and income. The researcher also asked for a performance evaluation of the Fadeli Regent, their attitude and people's behaviour in the Lamongan Regency.

The research location was in all of the districts in the Lamongan Regency; 27 in total. The respondents were divided proportionally by each sub-district, village, RW, RT, and by House (KK) level. The data obtained from the field was entered using the SPSS 17 program. After that, cleaning the data was the next step to check for data errors. The data was generalised and analysed regarding the phenomenon that occurs in the community.

The difficulties in this research were to do with finding respondents who really know the phenomenon of the declining voter turnout in the 2015 Local Election in Lamongan District. Not many respondents kept up to date and knew the issues to do with the candidacy in-depth. Most of the respondents only knew about the superficial phenomena related to the nomination process of the Regent of Lamongan Regency. For example, regarding the use of money in the political process, no-one knew directly. 
Although the evidence was difficult to obtain, the public can see the phenomenon taking place and it is enough to draw generalisations about the declining voter turnout in Pilkada 2015 Lamongan District.

\section{Result and Discussion}

\section{Political condition}

Lamongan District in the political context is a contested region in both the Legislative Election as well as the Local Election. This can be seen from the political party that is winning constantly changing in the Legislative Election. Since 2010, Lamongan District was led by Fadeli from the Democratic Party who previously served as the Regional Secretary (Sekda) of Lamongan District when Lamongan District was led by Masfuk. Fadeli Regent has held two periods, 2010-2015 and 2015-2020. The Legislative Election 2009 Lamongan District was controlled by two parties, namely Partai Kebangkitan Bangsa (PKB) and the PDI Perjuangan which got ten seats each in the Lamongan District Parliament (DPRD).

The parties that won seats in the middle board, such as Partai Amanat Nasional (PAN) with eight seats and Partai Golkar with six seats. The Partai Demokrat and PKNU got five seats each. The lower board political parties such as the Partai Patriot got three seats, and one seat each went to Partai Keadilan Sejahtera, Partai Hanura and Partai Persatuan Pembangunan. The result in the 2014 Election was that the Partai Demokrat won the highest vote, beating the previous winner, Partai Kebangkitan Bangsa (PKB). PDI Perjuangan was in the third position. Although the Partai Demokrat was the winner, the total vote was slightly different within the Partai Kebangkitan Bangsa.

The composition of the winning political party changed. Partai Demokrat which was in fifth position in the election in 2014, became the winning party that beat the PKB. However, because the total vote was slightly different, both parties got the same amount of seats in the District Parliament which were 10 seats each. PDI Perjuangan seats in DPRD declined from ten seats in 2009 to eight seats in the 2014 election. Meanwhile, Golkar got a constant seat number to the previous election which was six seats, whereas PAN which had eight seats in the 2009 election got six seats in 2014. In the Legislative Election 2014, Partai Gerindra rose significantly, including in Lamongan District. Partai Gerindra got six seats as PPP, while PKS and Hanura both got one seat each.

The leadership of the Fadeli Regent is based on Partai Demokrat consolidation. The total votes in the 2014 Legislative Election were sustained by many of Fadeli's family, who become legislative candidates. This led to the assumption that the Fadeli Regent built a political dynasty to secure their position as well as their policies in the council and parliament through positioning his family in the house.

Two of Fadeli's biological children who were elected to be one of the House of Parliament members in Lamongan District in the 2015-2020 period were Debby Kurniawan and Betty Nurfia Puspitasari. Debby is the leader of the Partai Demokrat Branch Council (DPC) Lamongan District. Fadeli's daughter-in-law, Retno Wardhani, was also elected to be a member of parliament. In addition, his two nephews were also elected in the House of Parliament; Nor Fathonah and Nahdliyah Kartika Agustin.

Five members of Fadeli's families, and the one who got the most votes, was Betty Nurfia Puspitasari, who is Fadeli's biological daughter with 15.815 total votes. The votes for her tend to increase in Lamongan District. The second was Retno Wardhani, who is Debby Kurniawan's wife with votes reaching 15.399. This phenomenon shows the strong influence and connections of Fadeli when he was running the government. It is interesting that this practice is common in order to secure positions among the political elites such as PKB and PDI Perjuangan.

In the legislative candidates elected from PKB, H.Abdul Gofur was the brother of DPC PKB leader, Makin Abbas. Makin Abbas himself become a member of House of Parliament (DPRD) in the East 
Java Province. It is the same with Fadeli's political opponent in the Local Election, Suhandoyo. His wife Zulaichah was elected with a significant 10.456 vote in total. This nepotism and dynastic politics will secure the position effectively, but it is not the best practice for long term regeneration and social welfare. This can be considered as a Human Rights Violation against any Indonesian Citizen above 21 years old, who legally can delegate themselves in parliament. It is an ethical problem between the effort to produce a qualified politician and the human rights sector.

The locations of the elected legislative candidates who are in the Fadeli Regent's family was within all of the electoral districts. In Lamongan District, there are five electoral districts. Lamongan 1 includes Deket Sub-District, Glagah Sub-District, Karangbinangun Sub-District, Lamongan Sub-District, Sarirejo Sub-District, and Tikung Sub-District. Lamongan 2 includes Bluluk, Kembangbahu, Mantup, Modo, Ngimbang, Sambeng and Sukorame sub-districts. Lamongan 3 covers Babat, Kedungpring, Pucuk, and Sugio Sub-District. Lamongan 4 covers Kalitengah, Karanggeneng, Maduran, Now, Sukodadi, and Turi Sub-District. Lamongan 5 covers Laren, Brondong, Solokuro and Paciran SubDistrict. The total votes from Fadeli's family members and relatives in the 2014 Legislative Election are as follows.

Table 1.

The list of elected candidates of the Regent family

\begin{tabular}{clccc}
\hline No & \multicolumn{1}{c}{ Name } & Status & Area & Total Votes \\
\hline 1 & Debby Kurniawan & BC & Lamongan 5 & 9.383 \\
2 & Betty Nurfia Puspitasari & BC & Lamongan 1 & 15.815 \\
3 & Retno Wardhani & $\mathrm{I}$ & Lamongan 2 & 15.399 \\
4 & Nor Fathonah & $\mathrm{N}$ & Lamongan 3 & 6.610 \\
5 & Nahdliyah Kartika Agustin & $\mathrm{N}$ & Lamongan 4 & 7.603 \\
\hline
\end{tabular}

Information: BC: Biological Children, I: In Law, N: Nephew

Source: KPUD Lamongan Regency

\section{Fadeli versus Suhandoyo}

The politics in Lamongan Regency post-Regent Masfuk, who led for two periods (2010-2005) and (2005-2010), was the competition between Fadeli and Suhandoyo. The qualified political opponent who could beat the Fadeli Regent was Suhandoyo. He is a member of the House of Parliament East Java Province from PDI Perjuangan. Their rivalry can be seen since 2010 Local Election, when both Fadeli and Suhandoyo were running for candidate. As the former Regional Secretary (Sekda), Fadeli was more ready and mastered the bureaucracy, supported by the previous leader, Regent Masfuk. The 2010 Local Election consisted of four pairs of candidates. Couples No.1, M. Tsalist Fahami and Subagyo from PKNU and Patriot Party, Couple No.2, Ongki Wijaya Ismail Putra and Basir Sutikno were promoted by individuals, Couple No.3, and Fadeli and Amar Saifudin were promoted by four political parties, namely PKB, PAN, Golkar Party and PD. Couple No.4 was Suhandoyo and Kartika Hidayati from PDI Perjuangan.

The 2010 Local Election was a very fierce competition between Fadeli-Amar Saifudin and Suhandoyo-Kartika Hidayati. Although only supported by PDI Perjuangan, they quietly resisted and gained a sufficient amount of votes to fight against Fadeli and Amar Saifudin. Fadeli-Amar Saifudin was the winner with a total vote of 40.91 percent while Suhandoyo-Kartika Hidayati earned 38.47 percent, with a difference of 2.44 percent. With this slight difference of total votes, it was enough for Suhandoto-Kartika Hidayati to conduct a lawsuit in appeal to the Constitutional Court. The result of the lawsuit was recalculating in several polling stations. Instead of gaining additional votes, the pair of candidates lost votes after the recalculating. They had 38.40 percent after the recalculating and Fadeli-Amar Saifudin earned more votes in the end with a total of 40.98 percent.

Although officially Fadeli-Amar Saifudin was declared the winner, as the losing party, Suhandoyo registered one more time in the following 2015 election. Suhandoyo was consistently consolidating 
at the grassroot level. The competition between the two candidates was becoming even more fierce, because Fadeli as the incumbent was trying really hard to secure their position by minimising opponents. The uniqueness of the 2015 Local Election between Fadeli and Suhandoyo was about spreading the rumour that they were exchanging their partner. Amar Saifudin with Suhandoyo, and Fadeli with Kartika Hidayati. Amar Saifudin from PAN was considered to have a strong mass base, as well as Kartika Hidayati, who is a member of the Provincial parliament from PKB.

As time got closer to the registration deadline, Fadeli made sure that he would be paired with Kartika Hidayati, while Suhandoyo was not paired with Amar Saifudin. Instead, he planned to pair up with Abdul Ghofur, who is a member of the Parliament (DPRD) of Lamongan District from PKB. Both of the parties had campaigned through various media such as banners, pamphlets, billboards, etc.

There were many rumours that had spread about Suhandoyo being supported by his party, PDI Perjuangan. As the Chairman of the PDI Perjuangan faction in the Parliament of East Java Province (DPRD), Suhandoyo certainly had a fanatic mass. Suhandoyo's failure to gain support from PDI Perjuangan was due to the conflict indication against DPC PDI Perjuangan Lamongan. The conflict was also brought to the level of the Party Consideration Council(DPP). This also affected Suhandoyo's position in the aftermath in PDI Perjuangan itself, as his power became weaker. On August 6th, 2015, Suhandoyo was dismissed from his position as a Chairman of Parliament PDI Perjuangan fraction for the East Java Province. This new formation in the party weakened Suhandoyo even further. He had no bargaining position in his own party. The shifting support of PDI Perjuangan from Suhandoyo toward Fadeli-Kartika Hayati indicated that most of the parties involved in the election were bribed by Fadeli. As an incumbent with considerable capital strength, this phenomenon is possible. This is the first time in history that all of the parties in the council agreed to support the incumbent.

\section{Factors contributing to the decline in turnout voters and the turnout voters in each sub-district}

The voter turnout existence in the Local Election reflects the participation of the community in expressing their opinions and choices. The presence of voters in every election (legislative, regional and presidential election) may vary. There are several factors causing the fluctuation in voter turnout such as the program and vision of the candidate's mission, the closeness of the candidate to the voter, the popularity of the candidate, their track record, the candidate's performance evaluation and the candidate's quality followed by the supporting political party that can influence voter turnout in general.

The socialisation conducted by the Lamongan Local Election Commission also influenced the attendance of voters in the election. The Local Election Commission of Lamongan Regency conducted socialisation with beginner voters all the way through to voters with disabilities (the disabled). The tendency of the voter turnout in every election in Lamongan Regency has been to decrease. The 2005 election had a $72 \%$ attendance rate compared to the 2010 election with $63.90 \%$, whilst the 2015 election had an attendance rate that was lower at $60.47 \%$. In the 2014 election, it was $71 \%$. This shows that there are factors that affect the attendance rate of the voters in each election. The comparison of the voter turnout in every election can be seen in Diagram 1.

The lower attendance level strengthens the argument of Dittrich \& Johansen (1983), that when political competition in Lamongan district tends to be dominated by one party or a strong figure, the competitors that appear will not significantly change voter turnout in every election.

From the 27 sub-districts, the highest voter presence was in Kembangbahu sub-district with $74.98 \%$. The second highest voter attendance rate was in Kecamatan Deket, at $74.57 \%$, but there was still a very low level of voter turnout in several sub-districts. There are three sub-districts with low voter attendance; they are Sekaran Sub-district, Laren Sub-district, and Maduran Sub-district.

The lowest voter turnout was in Sekaran Sub-district where only 39.40\% out of the total 42,201 voters did so. The second lowest voter turnout was in Laren Sub-district with $41.72 \%$ out of the total 
of 42.866 voters, while in Maduran Sub-district, it was $41.97 \%$ out of a total of 31.135 voters. As to the most voters, Paciran Sub-district with 73,130 voters had a lower voter turnout attendance with less than 50\%; precisely $48.89 \%$. In contrast, as the district with the lowest number of voters but a high level of turnout, Sukorame Sub-district had 17,104 total voters, which is $70.55 \%$. The most invalid votes was in Babat sub-district, with 2,238 voters out of 71,125 voters in total, while the least invalid number of votes was in Bluluk sub-district with only 225 voters out of 18,396 voters. Due to the Fadeli Regent's inharmonious relationship with Babat Sub-district society over the development of the Market, which did not benefit local society and led to protests against the government, the implication was the decrease of voter turnout in the region. The details of voter attendance in each sub-district can be seen in Table 2.

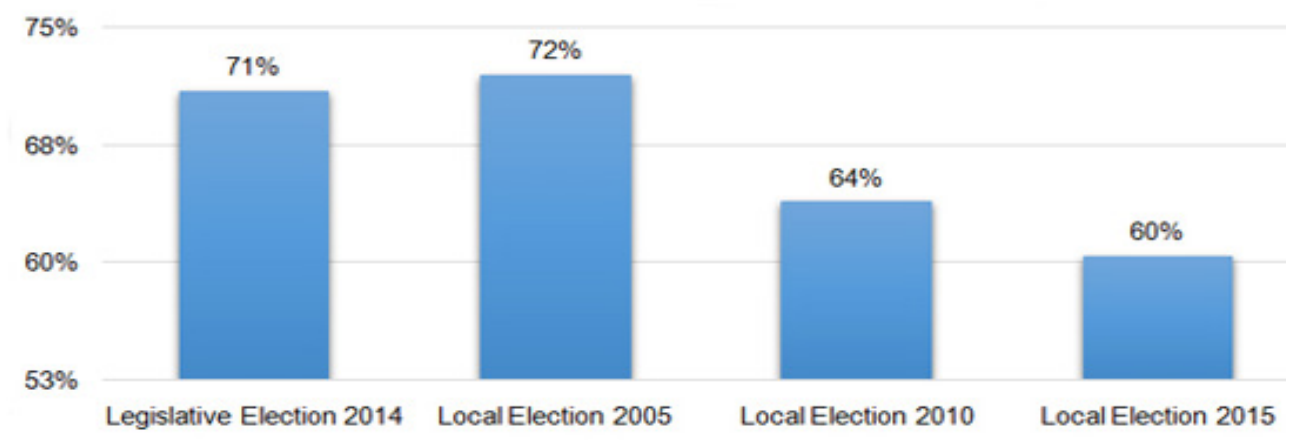

\author{
Diagram 1. \\ The comparison of Voter Turnout \\ Source: edited from the data from KPUD Lamongan District
}

The lowest voter turnout was in Sekaran Sub-district where only $39.40 \%$ out of the total 42,201 voters did so. The second lowest voter turnout was in Laren Sub-district with $41.72 \%$ out of the total of 42.866 voters, while in Maduran Sub-district, it was $41.97 \%$ out of a total of 31.135 voters. As to the most voters, Paciran Sub-district with 73,130 voters had a lower voter turnout attendance with less than $50 \%$; precisely $48.89 \%$. In contrast, as the district with the lowest number of voters but a high level of turnout, Sukorame Sub-district had 17,104 total voters, which is $70.55 \%$. The most invalid votes was in Babat sub-district, with 2,238 voters out of 71,125 voters in total, while the least invalid number of votes was in Bluluk sub-district with only 225 voters out of 18,396 voters. Due to the Fadeli Regent's inharmonious relationship with Babat Sub-district society over the development of the Market, which did not benefit local society and led to protests against the government, the implication was the decrease of voter turnout in the region. The details of voter attendance in each sub-district can be seen in Table 2.

The Local Election is a leader exchange process or in other words, it is a matter of leadership succession in democratic country. The successful implementation of the Local Election is an indicator of the success of democratic value implementation. The successful implementation of democratic values can be seen in the absence of fraud in its implementation, there being no conflict between candidates, and the presence of voters in the elections or the so-called voter turnout. The fluctuation of voter turnout is influenced by several factors, such as the maturity of the democracy. A country where democracy is established and mature is the United States, which has an actual voter turnout below 50 percent. This is because democratic values are very well established in all areas of life. Politicians can also be a role model and penetrate the value of democracy into the society. On the other hand, in countries where democratic levels are not yet well established or are even authoritarian, the rate of voter turnout is quite high, and could reach 90 percent. This is caused by the misunderstanding of the society participation value, which is not for the sake of the democracy itself but more for political mobilisation. 
Table 2.

Voter turnout in each sub-district

\begin{tabular}{|c|c|c|c|c|c|c|}
\hline No & Sub-district & Voter & The vote user & Valid Vote & Unvalid Vote & Total Vote \\
\hline 1 & Babat & 71,125 & $35,828(50.37 \%)$ & 33,59 & 2,238 & 35,828 \\
\hline 2 & Bluluk & 18,396 & $12,907(70.16 \%)$ & 12,675 & 225 & 12,907 \\
\hline 3 & Brondong & 56,443 & $25,844(45.78 \%)$ & 24,973 & 865 & 28,85 \\
\hline 4 & Deket & 34,381 & $25,641(74.57 \%)$ & 24,897 & 744 & 25,641 \\
\hline 5 & Glagah & 33,191 & $22,249(67,03 \%)$ & 21,332 & 695 & 22,249 \\
\hline 6 & Kalitengah & 27,497 & $17,441(63.42 \%)$ & 16,881 & 560 & 17,441 \\
\hline 7 & Karangbinangun & 31,436 & $20,118(63.99 \%)$ & 19,462 & 656 & 20,118 \\
\hline 8 & Karanggeneng & 36,855 & $20,168(54.72 \%)$ & 19,622 & 546 & 20,168 \\
\hline 9 & Kedungpring & 48,790 & $30,582(62.68 \%)$ & 29,674 & 908 & 30,582 \\
\hline 10 & Kembangbahu & 39,299 & 29,467 (74.98\%) & 28,775 & 692 & 29,467 \\
\hline 11 & Lamongan & 50,750 & $37,093(73.08 \%)$ & 35,185 & 1,908 & 37,093 \\
\hline 12 & Laren & 42,866 & $17,887(41.72 \%)$ & 17,337 & 550 & 17,887 \\
\hline 13 & Maduran & 31,135 & $13,070(41.97 \%)$ & 12,444 & 626 & 13,070 \\
\hline 14 & Mantup & 35,984 & $26,158(72.69 \%)$ & 25,175 & 983 & 26,158 \\
\hline 15 & Modo & 41,071 & $26,451(64.40 \%)$ & 25,253 & 1,198 & 25,451 \\
\hline 16 & Ngimbang & 37,122 & $26,694(71.90 \%)$ & 25,911 & 783 & 26,694 \\
\hline 17 & Paciran & 73,130 & $35,693(48.89 \%)$ & 34,333 & 1,360 & 35,683 \\
\hline 18 & Pucuk & 42,487 & $20,171(47.47 \%)$ & 19,290 & 881 & 20,171 \\
\hline 19 & Sambeng & 41,111 & $30,259(73.60 \%)$ & 29,685 & 574 & 30,259 \\
\hline 20 & Sarirejo & 19,977 & $14,145(70.80 \%)$ & 13,828 & 317 & 19,977 \\
\hline 21 & Sekaran & 42,201 & $16,628(39.40 \%)$ & 15,964 & 664 & 16,628 \\
\hline 22 & Solokuro & 37,648 & $18,981(50.41 \%)$ & 18,486 & 495 & 18,981 \\
\hline 23 & Sugio & 49,805 & $32,419(65.09 \%)$ & 31,370 & 1,049 & 32,419 \\
\hline 24 & Sukodadi & 44,890 & 31,967 (71.21\%) & 31,122 & 845 & 31,967 \\
\hline 25 & Sukorame & 17,104 & $12,067(70.55 \%)$ & 11,697 & 370 & 12,067 \\
\hline 26 & Tikung & 34,006 & $24,804(72.94 \%)$ & 23,813 & 991 & 24,804 \\
\hline 27 & Turi & 41,792 & $28,692(68.65 \%)$ & 27,928 & 764 & 28,692 \\
\hline
\end{tabular}

This kind of phenomena occurred in the new order era and post-new order. Society's participation remained high in the election in the Suharto era, with a $90 \%$ voter turnout in general. However, this percentage decreased in the reformation era, both in the legislative election and presidential election, which was only $70 \%$. This indicates the emergence of freedom, either the freedom to vote for a political party or a candidate, or the freedom to not vote for a political party or candidate. This is since non-voting (abstain) is an option as well, and a part of freedom.

The decline phenomenon of voter turnout also occurred in the elections in Lamongan District Year 2015. From the trend that occurred, the voter turnout declined in the 2005 local election, 2014 legislative election, and then the 2015 local election. As in the elections in 2005, the attendance rate reached 72 percent. This is higher than the attendance rate in the 2014 legislative election where the attendance rate was 71 percent. The attendance rate had started falling since the elections in 2010, down to 63.9 percent. In the 2010 Local Election, the candidate who was running for Regent was incumbent, because Masfuk had led twice in the stated period. During Masfuk's leadership, society perceived him as a good leader. As an Entrepreneur Regent, he gave off different nuances to the bureaucracy of the Lamongan Regency. With a background as the Managing Director of the EKA Group with seven subsidiaries, it brought in an entrepreneur spirit into the bureaucracy environment 
of Lamongan Regency. This skill intended to manage the creativity available by providing the best service possible to the community. Masfuk was named as the best Regent in Indonesia in 2008, especially in the trade, tourism, and investment sectors. The Regional Trade, Tourism and Investment Award (RTTI) Award was received by him at the Indonesia Regional Investments Forum (IRIF), attended by both domestic and foreign investors.

The causes of the decline in voter turnout in the 2015 elections were as follows. Firstly, the majority of people prefer to go to work instead of voting for a new leader. A total of 42.40 percent of voters did not attend the election due to work. People were more concerned with working than attending the Local Election. The Local Election itself was held on Wednesday, December 9th 2015. Although the government appealed that the day should be a public holiday, some of the private workers were still working. There were those who chose to work instead of using the right to vote. The majority of Lamongan people are farmers. The segmentation of some farmers also thought that it was better to be at the rice field than to choose not get money or 'sangu'. This is in accordance with what Downs (1957) put in his book, "An Economic Theory of Democracy" on The Basic Logic of Voting which judges that voters will choose a candidate who benefits them.

"The benefits that the voter considers when making their decisions are streams of utility derived from government activity. Actually, this definition is circular, because we define utility as a measure of the benefits in a citizen's mind which he uses to decide on an alternative course of action. Given the highest utility, ceteris paribus, he acts to his own greatest benefit" (Downs 1957:36-46).

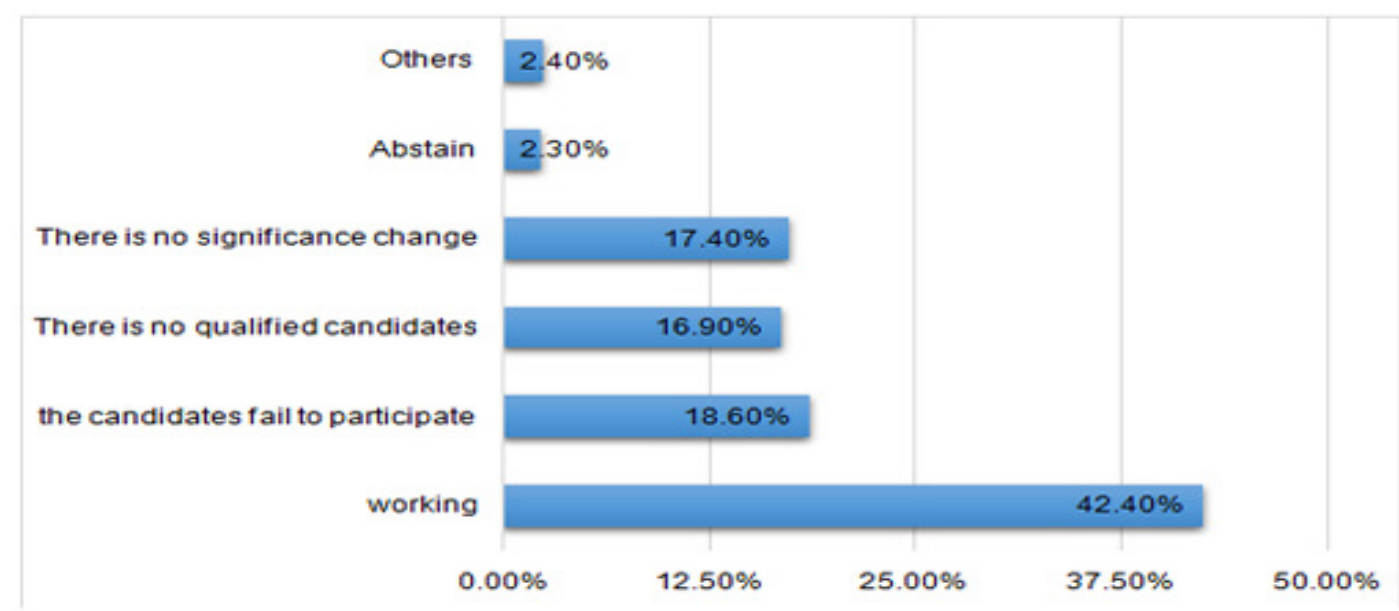

Diagram 2.

The factors that caused voter turnout to be down in the 2015 elections

Voters prefer to go to work because of their material orientation and the absence of 'Sangu'. A collective evaluation of the economic performance of the government also has a major impact on voting behaviour, as revealed by Lewis-Beck \& Lockerbie (1989). Voters choose a party or a candidate based on the expected utilities. As stated by Aldrich (1976), the choice of the citizens will be influenced by the different benefits from each candidate. Aldrich, quoting Riker \& Ordeshook (1968), made the equation $\mathrm{R}=\mathrm{PB}+\mathrm{D}-\mathrm{C}$ as a development of the Down equation (1957). The model of potential-voter behaviour is $\mathrm{R}=\mathrm{PB}-\mathrm{C}$. $\mathrm{R}$ is Reward; if the positive rewards for society are predicted, they will choose the candidate. $\mathrm{PB}$ is the probability that the voter vote will be influenced by the benefit that the voter receives from the favoured candidate. $\mathrm{D}$ is the duty of the citizen, while $\mathrm{C}$ shows the physical, decisions, and other costs associated with voting.

The people desire to 'Sangu' when in local election, as an expression of maximising what benefits can be gained from the regent candidates or a political party. This minimises the expenses incurred 
(Colomer 1991, Riker \& Ordeshook 1968). When the expectation to get 'Sangu' is negative or unfulfilled, then the voters will tend to abstain in the election.

The unfulfilled 'Sangu' and the evaluation of the economic condition of Lamongan District caused the voters to prioritise work rather than to use their voting rights. This was, to them, maximising what the voters could get out of it. Moreover, the absorption of low labour made the people of Lamongan Regency prefer to work out of town or even to become immigrant workers (Lewis 1982, Fernandez 2006, Rosenstone et al. 1986, Foster 1983, Riker \& Ordeshook 1968, Capron \& Kruseman 1988).

Second, as many as 18.60 percent of voters also considered not voting because the candidates that they supported failed to follow through with the nomination. There are several names that have influence in the community, such as Suhandoyo, the member of East Java Parliament from PDI Perjuangan. The Former Vice Regent Amar Saifudin of the Partai Amanat Nasional (PAN) was not paired with Suhandoyo. As a former Vice Regent, Amar Saifudin has fanatical voters, especially from PAN itself. However, when Suhandoyo was paired with Kartika Hidayati in the 2010 local election, they obtained a significant vote with a slight different total vote of 2.58 percent. Suhandoyo is one of the toughest political opponents of Fadeli and so Fadeli's efforts to secure the seat of Lamongan Regent for the second time was by aligning with all political parties that had seats in the Lamongan District Legislative. Not only that, but Fadeli also made Kartika Hidayati his vice regent candidate. This strategy was to prevent Suhandoyo running as a candidate again.

The emergence of political cartels began in Western Europe in Denmark, Germany, Switzerland and the United Kingdom. This is where the ruling political party tends to make its inhibitions known by taking refuge in its favourable rules (status quo). This is aimed at securing the position of the political party in the political system, lowering the participation rate overall including the involvement of other political parties. According to Detterbeck (2005), there are three dimensions of analysis in relation to cartel political parties: (1) Organisational Structures, where there is an influence of the power of the political parties in the structure of public office. The public offices are dominated by party executive organs and decision-making procedures in the internal domains, (2) Political Role, which is the gap of the symbolic relationship between society and the state. Political parties should be a bridge between the community and the state are a representative function of the community. They turn out to be more focused on the executive function in government. The leaders of the political parties focus more on parliamentary policy-making than interpreting party manifestos or political discussions at party congresses. (3) Party competition, where political parties create a barrier against a new party. The new party is not always inhibited. They could enter the system but they must be in accordance with the rules set by the party that is conducting the cartel. The explanation of the dimensions of analysis of cartel parties can be seen in Table 3 .

The struggle and effort involved to carry out cartel politics in the 2015 Local Election in Lamongan Regency was conducted by the incumbent by controlling seats in DPRD through their children, and families who had already sat in Lamongan District Parliament from the 2014 legislative election results. The Partai Demokrat, in this case, also tried to create a cartel for the regent candidates in the first stage by controlling the parliament. This was done by multiplying the seats and mastering the Chair of the board (Koole 1996, Kitschelt 2000, Blyth \& Katz 2005).

Debby Kurniawan, who is the son of Fadeli, served as the Chairman of the DPC Partai Demokrat Lamongan, which incidentally is a member of the Parliament of Lamongan District. PD, as the party that gets the highest vote, also seized the position of the Chairman of the Parliament of Lamongan District occupied by the Treasurer of the DPC Partai Demokrat, Kaharudin. Fadeli Regent also tried to embrace all political parties in the parliament, for them to support her. Fadeli, through PD, also tried to control Lamongan District Council to create protective walls against the emergence of other candidates. Suhandoyo, who plans to run for candidate a second time, did not get full support from his own party. From the perspective of Detterbeck, in the cartel party analysis dimension, Suhandoyo, in his organisational structure, is in conflict with Head of a Subsidiary (PAC) PDI Perjuangan. This 
affects the candidate selection in the internal structure of PDI Perjuangan. In the end, PDI Perjuangan supported Fadeli as the candidate for Regent. The powerful ability of the cartel created by Fadeli in the local election makes democracy merely a social stability achievement, and not a social change (Katz \& Mair 1995).

Table 3.

The three analytical dimensions of cartel parties

\begin{tabular}{ccc}
\hline $\begin{array}{c}\text { Analytical } \\
\text { dimension }\end{array}$ & Main characteristics & Empirical indicators \\
\hline $\begin{array}{c}\text { Organisational } \\
\text { structures }\end{array}$ & $\begin{array}{c}\text { Ascendancy of the "party in public office". } \\
\text { Vertical striation. }\end{array}$ & $\begin{array}{c}\text { Composition of national party executives. } \\
\text { Candidate selection. } \\
\text { Election campaigning. } \\
\text { Internal policy decision-making. }\end{array}$ \\
\hline Political role & Estrangement from society. & $\begin{array}{c}\text { Involvement of party members. } \\
\text { Involvement of interest groups. } \\
\text { Importance of state resources. }\end{array}$ \\
\hline $\begin{array}{c}\text { Party } \\
\text { Competition }\end{array}$ & Cartelization of privileges. & $\begin{array}{c}\text { Access to state privileges. } \\
\text { Style of party competition. }\end{array}$ \\
\hline
\end{tabular}

Suhandoyo is the most powerful and potential candidate as Regent in the 2014-2019 period. On the other hand, as Fadeli wants to secure his regime and position, he should reduce the power of Suhandoyo by making Kartika Hidayati the Vice Regent Candidate. Fadeli Regent has tried not to give any chance or opening to his strongest opponent, Suhandoyo.

There was a discourse made that Suhandoyo would take Amar Saifudin, but this could not be realised because PDI Perjuangan and PAN decided to support the Fadeli-Kartika Hidayati pair. PDI Perjuangan, which is the Suhandoyo party, decided to give its support to Fadeli. The decision of PDI Perjuangan to support Fadeli was also influenced by the internal conflict in DPC PDI Perjuangan. The new management of DPD PDI Perjuangan changed the political map at the internal level within PDI Perjuangan. The position of Suhandoyo in PDI Perjuangan was not as strong as it used to be, so it made him lose hope of becoming a candidate for Regent from PDI Perjuangan (Katz 2001).

In the final seconds, Suhandoyo also planned to go forward with Abdul Ghofur, the Vice Chairman of Lamongan District Legislative Parliament, but failed because PKB nominated Kartika Hidayati and paired her with Fadeli. There is an indication that Fadeli gave Kartika Hidayati a dowry to be his vice, which included all political parties in the DPRD supporting Fadeli. In a competitive democracy era, it is rather difficult to mobilise support from political parties, let alone for just one vote in favour of one candidate. Fadeli was indicated to have bought all of the parties in the council to nominate him and to close down Suhandoyo's chances to step forward as a candidate for Regent.

By not passing, the candidate of the regent had a very influential impact, especially in the base areas such as Maduran Sub-district, which is the base of PDI Perjuangan. The voter turnout was only 41.97 percent, while in the Laren Sub-district which was the base for PAN, the total voter turnout gathered was even lower, at 41.72 percent. The lowest voter turnout was in the Sekaran Sub-district, which only gained 39.40 percent. Sekaran Sub-district is the base of PDI Perjuangan. The PDI Perjuangan vote earned the highest number of votes, at 2,055. PDI Perjuangan votes in the Maduran Sub-district were also high at 3,402 votes. Similarly, the vote of PAN in the Laren Sub-district gained the highest result with a total of 2,400 votes. This shows that a political party figure who wants be a candidate but fails to be nominated has a positive correlation to voter turnout.

The powerful influence of the political party figures who are not running on the presence of voters can be seen from the diagram below, which explains the level of voter presence viewed from the party's choice in the Legislative Election in 2014. From the diagram below, it can be seen that the 
majority of the abstaining voters were constituents of PDI Perjuangan, which is actually Suhandoyo's party amounting to $33.30 \%$. The second most abstained voter number was for PAN, the party of Amar Saifudin who is the Vice Regent. PAN voters who were absent in Pilkada 2015 made up 25\%. The three parties who had been consistent for not voting or voting in the 2014 Legislative Election amounted to $16.70 \%$. Other absent voters came from PKB constituencies with $8.40 \%$, and Gerindra and PPP respectively with $8.30 \%$. This is evidence that when the competition in the elections did not involve fairness, the elections tended to be dominated by one candidate pair and as a result, it decreased the attendance rate of the voters or in other words, decreased the voter turnout.

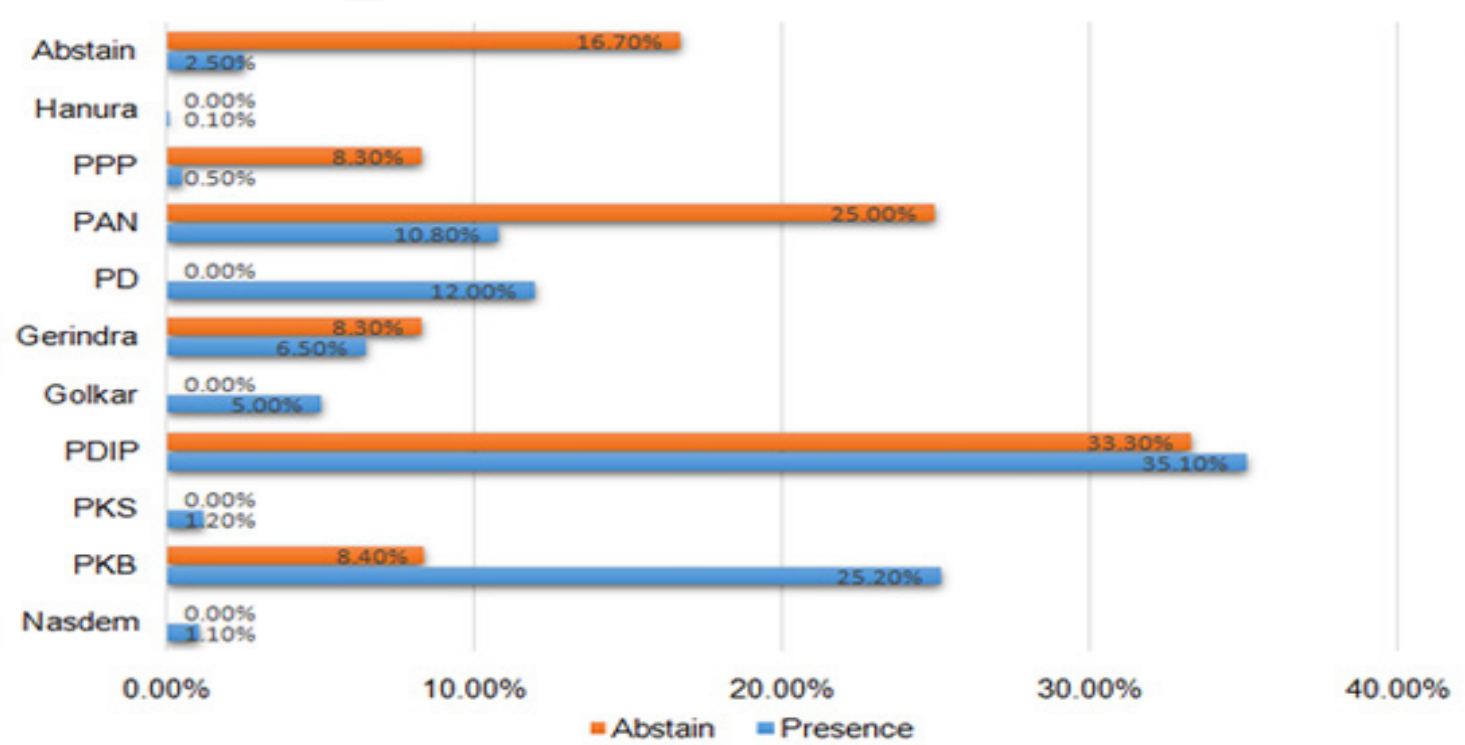

Diagram 3.

Voter turnout from the Legislative election 2014

Third, the cause of the decline of voter turnout is that there are no suitable and qualified candidates. This amounted to 16.90 percent. Lamongan Election 2015 consisted of three pairs of candidates, two from individuals and only one partner from a political party. The candidates as individuals were Mujianto-Sueb and Nursalim-Edy Wijaya. The couple who were being supported by a political party were Fadeli-Kartika Hidayati, who was strangely fully supported by all political parties sitting on the council. The eight political parties are PD, PKB, PDI Perjuangan, Golkar, Gerindra, PKS, PAN and the Hanura. When the candidate for the post of regent is only three candidate pairs, the public will already think that the winner is going to be Fadeli-Kartika Hidayati. The Fadeli-Kartika Hidayati pair had very strong political capital when compared to the other two couples from the individual channels. The capabilities of Fadeli's political capital can be seen from all of the political parties in Parliament of Lamongan Regency, which embraced supporting him with Kartika Hidayati in the local election.

The absence of qualified candidates can be analysed by the amount of the total voters for the candidates who failed to register and nominate themselves as candidates as described Diagram 4. This shows that voters will vote their chosen candidates, expecting that they will get a positive impact afterwards (Owen \& Grofman 1984, Simon 1955, Aldrich 1993). However, if the expected candidates don't meet their expectations or fail to nominate themselves, they tend to resign or abstain from their right to vote.

The majority of the voters who didn't use their right to vote come from the Suhandoyo-Kartika Hidayati supporters in the 2010 Local Election (50\%). The second with the most supporters was Fadeli-Amar with $33 \%$ and $16.70 \%$ were abstain voters. As many as $50 \%$ of the majority of Suhandoyo-Kartika 
voters were fanatical supporters in the 2010 Local Election. Similarly, Amar Saifudin supporters did not use the right to vote because the candidate did not run for Lamongan Regent 2015.

Two individual candidates were not been able to convince the voters, due to their lack of experience in the government sectors. A strong candidate was Fadeli, who was an incumbent with experience in government. However, Fadeli was also perceived as a negative candidate, especially related to the indication of corruption and collusion. Moreover, their ability to embrace the eight political parties was perceived by the people as Fadeli conducting cartel politics by inhibiting all of the considering candidates who might have been able to defeat him in the elections. Suhandoyo Fadeli was the toughest rival in the 2010 local election.

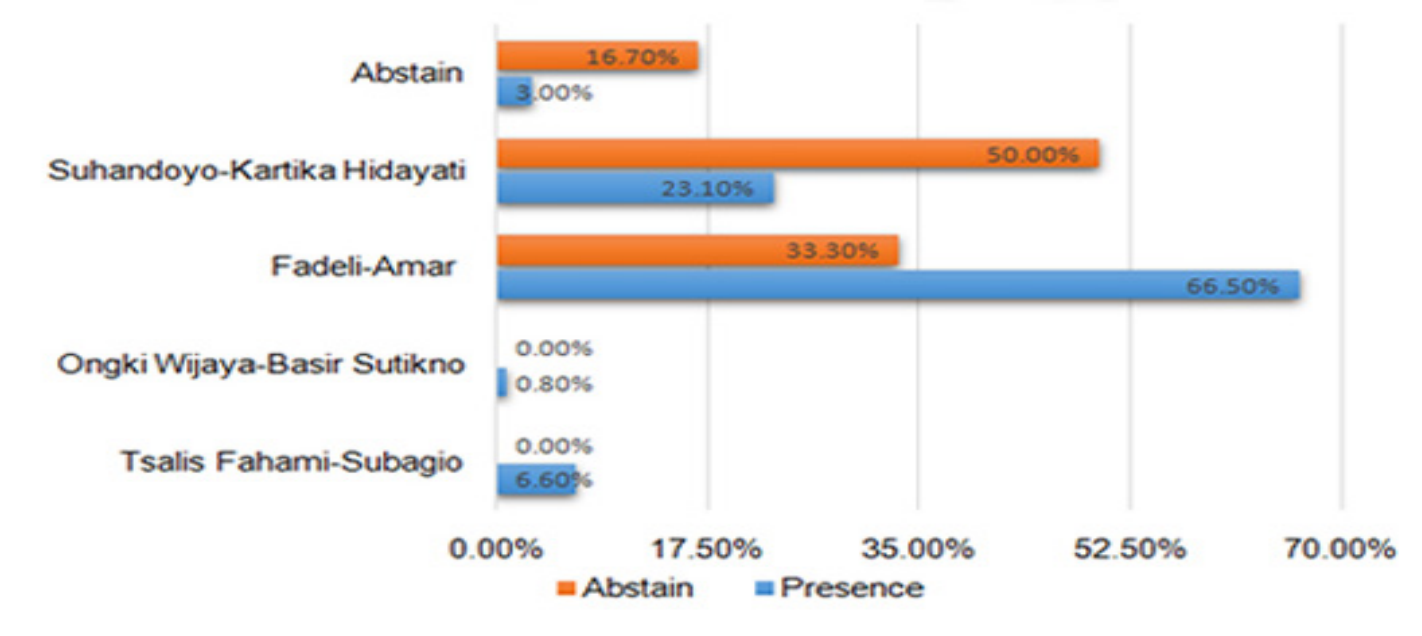

Diagram 4.

The abstaining voters in the Presidential Election 2015, from voters in the Local Election 2010

Two individual candidates were not been able to convince the voters, due to their lack of experience in the government sectors. A strong candidate was Fadeli, who was an incumbent with experience in government. However, Fadeli was also perceived as a negative candidate, especially related to the indication of corruption and collusion. Moreover, their ability to embrace the eight political parties was perceived by the people as Fadeli conducting cartel politics by inhibiting all of the considering candidates who might have been able to defeat him in the elections. Suhandoyo Fadeli was the toughest rival in the 2010 local election.

Although an incumbent, the public also perceives that Fadeli has so many indications of corruption. Fadeli is perceived by the public as having bought all political parties on the board to fully support them in the 2015 elections. Fadeli's did this to embrace all parties to stem the tide of the opponents who could otherwise endanger his position, like Suhandoyo. Based on the field data, it is seen that the majority of the community (57 per cent) rated that they "Agreed" that Fadeli gave big dowry to all political parties in Lamongan District Council to support him, while the rate of "Strongly Agree" was 4 percent. People who rated "Less Agree" was as much as 19 per cent and those who rated "Disagree" was 20 per cent. In the electoral election era, people's perceptions are very important, even for an entirely new candidate who has to build their public perception from an early age to shape the opinion that ultimately influences the voter's political attitudes and behaviour. It means that when a candidate is perceived negatively, it will affect their electability.

Four; the decline of voter turnout is due to the absence of significant changes in the Lamongan Regency by as much as 17.4 percent. Complaints from the majority of the community are related to infrastructure such as roads, bridges and irrigation channels. Infrastructure development is rated as being less than 19.9 percent. The poverty reduction factor of the two communities' complaints is 17.4 percent. The third community complaint is job opportunities and employment, at 15.2 percent. 
Lamongan Government has repaired several roads but there are still so many road that have not yet been redone. As for the roads in Pucuk Village in the Pucuk Sub-district, Lamongan, due to the slow progress being made, the road has been planted with banana trees to either side so as not to endanger road users. Similarly, many bridges are still damaged, such as two bridges on the interdistrict highway that connects Gembong Village in the Babat-Sekaran Sub-district. It has been years the main bridge received huge damage and needed to be reconstructed, yet it has been neglected. The sub-district leader has submitted this request to Lamongan District Government, but there has been no response yet. Damaged roads also occur in Bluluk-Sukorame Sub-district, which caused a demo by the local members of society who demanded for the local government to fix the road.

The allegation of financial irregularities is known. This was after they found out a gap in the figures between WBL financial statements with the amount that went into the PAD APBD in 2010. WBL's income is Rp 6.25 billion every year, with 80 percent from ticket sales. In 2010, WBL's net profit was Rp.29.469.384.178, with an income tax of Rp.12.629.736.074. However, it was assumed that there were economic games being played in terms of their accounting operations. They made the November WBL as if they were having a severe loss, when the net profit should have been Rp.31.662.587.502.48. Referring to the addendum of the agreement in which $45 \%$ of shares are controlled by Lamongan Local Government, the money coming into the regional treasury should have been Rp.14.248.164.376,1. However, it was reported to be only Rp.11.250.000.000. Then there was the alleged loss of Rp.2.998.164.376,1 or almost Rp 3 billion. This perception makes society even more sceptical about the election because it is clear who is going be the winner, and so there will be no massive changes in the aftermath.

As much as 2.3 percent of the voters abstained. The apolitical parts of society, who never use their right to vote, do not consider that the use of the right to vote as a citizen is an important obligations. Moreover, they think that there will be no significant changes in relation to them in participating or using their right to vote personally. This makes them uninterested in using their rights (Sigelman et al. 1985, Luttbeg 1985).

The similar problem of the decrease in voter turnout is due to the hesitation of the voter towards the candidates, and about how the policy will not impact on their social welfare which can be seen from the research results by Franklin in 22 countries. It said that the impact of globalisation will necessarily decrease the voter turnout because of the importance of capital owners who can influence the elected candidate because they are not independent.

".......voters responding to the character of elections in terms of the extent to which they can see their vote possibly has policy implications. Globalisation would operate much like a declining executive responsiveness, reducing the power of governments to make policies independently of international obligations and the realities of the international market place" (Franklin 2004:179).

The declining of voter turnout can also occur in a stable democratic country (Blais 2000, Gray \& Caul 2000). The decline in voter presence in Canada is influenced by classical socio-demographics of age and education (Wolfinger \& Rosenstone 1980, Blais 2000). Older people are more likely to use their right to vote than younger people, who are called millennials. The millennial generation is likely to remain unstable in relation to determining their choice of candidates and political parties. This generation still need guidance from their parents or the generation above them. Moreover, they tend to be less interested in politics. The low attendance of newbie voters and young voters is a natural generational effect. The older the people are, the more likely they are to use their political rights. Education emerged as the more interesting paradox. The higher the education level, the easier it is to choose who to vote for than the less educated. The number of educated people is also increasing. Theoretically, this tendency should increase participation in every election, but in fact, on the contrary, educated society is more vulnerable to stopping from time to time in using their voting rights. 


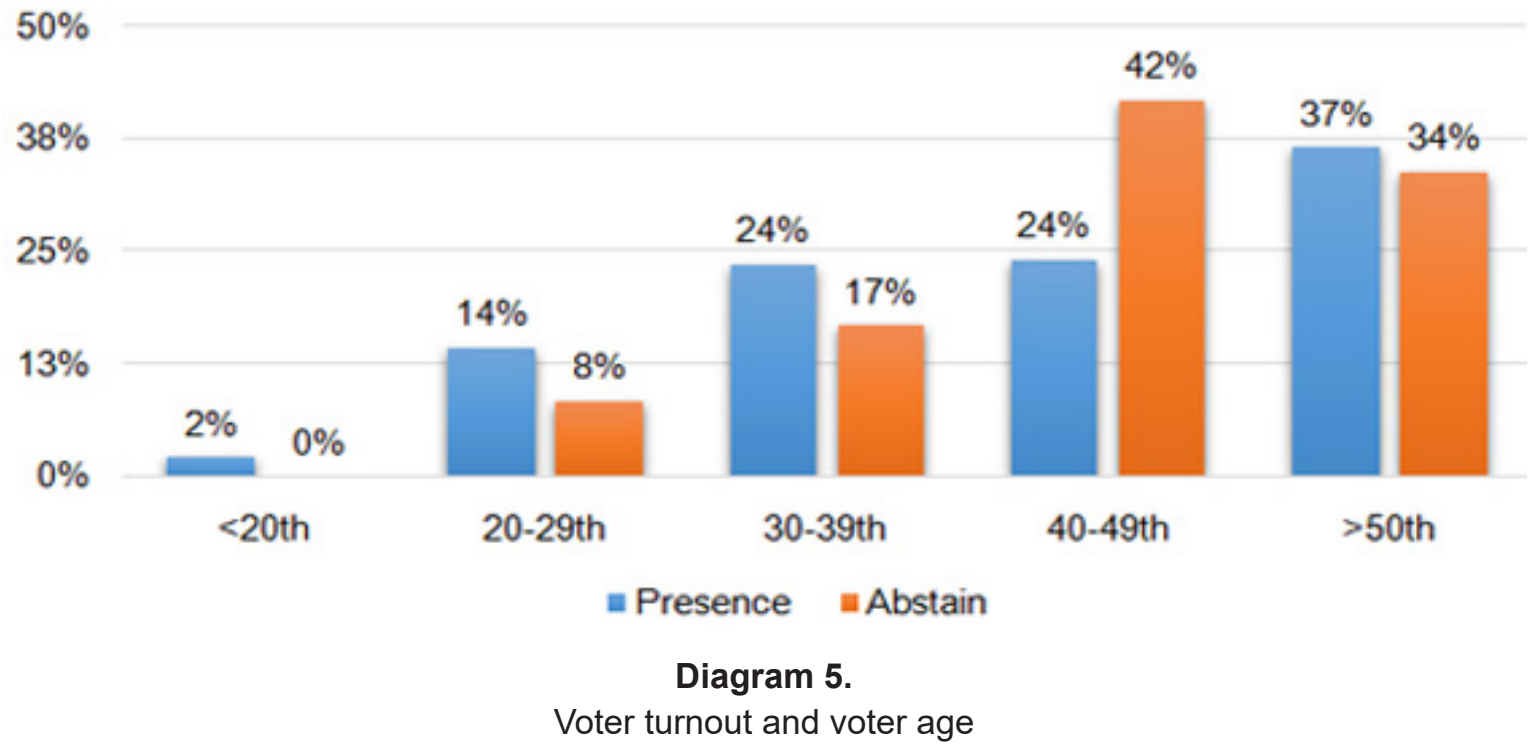

The above diagram denies what was proposed by Wolfinger \& Rosenstone (1980) and Blais (2000), that socio-demographic factors such as those of a young age having a lower attendance rate in the election. In the local election in 2015 , everything went in reverse; the abstain vote was not coming from the millennial generations but from the older generation (40-49) by as much as 41.70 percent. Most people aged $>50$ years amounted to 33.70 percent and the third largest community sector was those aged 30-39 years, who accounted for as much as 16.70 percent. This indicates that people who do not use their right to vote express their disappointment over existing political conditions, such as the dominance of the Fadeli Regent in contest, and there having been no significant changes in the economy and/or infrastructure.

\section{Conclusion}

The voter turnout in the Lamongan District Election in 2015 was lower than the previous elections, in 2010, 2005 and 2014 respectively. The dominant factor that decreased the attendance rate was that people preferred to work instead of using their voting rights. This is a public expression that the fulfilment of their economic needs is more urgent and considered more important than the use of their political rights. Economic conditions are difficult, so it requires working outside of Lamongan including abroad as migrant workers spread across various countries such as Malaysia, Singapore, Hong Kong, Brunei, Saudi Arabia and Qatar. A collective evaluation of the economic performance of the Fadeli Regent had a major impact on voting behaviour as revealed by Lewis-Beck \& Lockerbie.

Society does not use their right to vote, which is also based on material orientation. They are still hoping to get pocket money "sangu" from the regent candidate. Sangu could be money or goods that are considered a substitute for the activities undertaken for choosing the candidate. This is maximising the benefits and minimising costs, as proposed by Anthony Down. Society therefore uses economic principles in choosing who to vote for.

Candidates failing to become candidates for the Local Elections become the second factor of the decrease in voter turnout. Suhandoyo and Amar Saifudin, who had fanatical constituencies, when not running significantly reduced the attendance rate, especially for the constituents of the PDI Perjuangan and PAN. One dimension in analysing Cartel Parties in Western Europe was stated by Detterbeck, who states that party competition tends to be dominated by an old party and that it will try to build protective walls against new parties. This was done by the candidate themselves (Cartel Candidate) by embracing all political parties in Lamongan District Council as a protective wall against Suhandoyo. All of the party agreed to vote and support the Fadeli-Kartika Hidayati pair in becoming Candidate Regent-Vice Regent 2015-2020. Another factor that makes the attendance rate 
drop is that there are no significant changes as long as Fadeli serves as the Regent and there are no other suitable candidates. In terms of socio-demographic age, especially in relation to the young ones such as in Canada, the level of attendance was low in the elections, which is in contrast to the Lamongan Election in 2015. On the contrary, the mature voters who chose not to vote do so because it is one way for them to protest due to their candidate having failed in advance of becoming a candidate for regent.

\section{References}

Aldrich JH (1976) Some problems in testing two rational models of participation. American Journal of Political Science, 713-733.

Aldrich JH (1993) Rational choice and turnout. American Journal of Political Science, 246-278.

Blais A (2000) To Vote or Not to Vote? The Merits and Limits of Rational-Choice Theory. Pittsburgh, PA: University of Pittsburgh Press.

Blyth M \& Katz R (2005) From catch-all politics to cartelisation: The political economy of the cartel party. West European Politics, 28 (1):33-60.

Burnham WD (1965) The changing shape of the American political universe. American Political Science Review, 59 (1):7-28.

Capron H \& Kruseman JL (1988) Is political rivalry an incentive to vote?. Public Choice, 56 (1):3143.

Colomer JM (1991) Benefits and costs of voting. Electoral Studies, 10 (4):313-325.

Detterbeck K (2005) Cartel parties in Western Europe?. Party Politics, 11 (2):173-191.

Downs A (1957) An Economic Theory of Democracy in The Basic Logic of Voting. New York: Harper \& Row Publishers.

Dittrich K \& Johansen LN (1983) Voting turnout in Europe, 1945-78: Myths and realities. In: H Daadler \& P Mair (eds). Western European party systems (pp. 95-114). London: Sage

Foster CB (1983) The performance of rational voter models in recent presidential elections. American Political Science Review, 78 (3):678-690.

Franklin MN (2004) Voter Turnout and Dynamics of Electoral Competition in Established Democracies since 1945.

Gray M \& Caul M (2000) Declining voter turnout in advanced industrial democracies, 1950 to 1997 : The effects of declining group mobilization. Comparative political studies, 33 (9):1091-1122.

Jackman RW (1987) Political institutions and voter turnout in the industrial democracies. American Political Science Review, 81 (2):405-423.

Katz RS (2001) The problem of candidate selection and models of party democracy. Party politics, 7 (3):277-296.

Katz RS \& Mair P (1995) Changing models of party organization and party democracy: The emergence of the cartel party. Party politics, 1 (1):5-28.

Koole R (1996) Cadre, catch-all or cartel? A comment on the notion of the cartel party. Party politics, $2(4): 507-523$.

Kitschelt H (2000) Citizens, politicians, and party cartellization: Political representation and state failure in post-industrial democracies. European journal of political research, 37 (2):149179.

Lewis-Beck MS \& Lockerbie B (1989) Economics, votes, protests: Western European cases. Comparative Political Studies, 22 (2):155-177.

Luttbeg NR (1985) Attitudinal Components of Turnout Decline. Social Science Quarterly, 66 (2):435.

Owen G \& Grofman B (1984) To vote or not to vote: The paradox of nonvoting. Public Choice, 42 (3):311-325. 
Powell GB (1986) American voter turnout in comparative perspective. American Political Science Review, 80 (1):17-43.

Radcliff B (1992) The welfare state turnout, and the economy: A comparative analysis. American Political Science Review, 86:444-454.

Radcliff B (1996) Turnout and the economy. Comparative Political Studies, 29:718-723.

Riker WH \& Ordeshook PC (1968) A Theory of the Calculus of Voting. American political science review, 62 (1):25-42.

Rosenstone SJ, Hansen JM \& Kinder DR (1986) Measuring change in personal economic wellbeing. Public Opinion Quarterly, 50 (2):176-192.

Rosenstone S \& Hansen M (1993) Mobilization, Participation, and Democracy in America. New York: Macmillian.

Simon HA (1955) A behavioral model of rational choice. The quarterly journal of economics, 69 (1):99-118.

Sigelman L, Roeder PW, Jewell ME, \& Baer MA (1985) Voting and nonvoting: A multi-election perspective. American Journal of Political Science, 749-765.

Wolfinger R \& Rosenstone SJ (1980) Who Votes? New Haven, CT: Yale University Press. 